\title{
SUMBER HISTORIS PANCASILA SEBAGAI DASAR NEGARA \\ TANIA ALIFA SUKMA
}

TANIALIFA2002@GMAIL.COM

20220089

STIE AKBP KBP PADANG

\section{A.PENDAHULUAN}

Pendidikan Pancasila dan Kewarganegaraan merupakan salah satu mata pelajaran yang ada di setiap jenjang pendidikan. Pendidikan pancasila dan kewarganegaraan merupakan mata pelajaran yang berisikan materi yang ber-hubungan dengan nilai-nilai yang ada didalam Pancasila. Pendidikan Pancasila dan Kewarganegaraan ini sering dikaitkan dengan penanaman moral, akhlak, karakter peserta didik. Selain itu pendidikan pancasila berkaitan dengan Sumber Historis,Sosiologis,Politik Pendidikan Pancasila. Hal ini ditunjukkan dengan tujuan dari mata pelajaran pendidikan Pancasila dan Kewarganegaraan yakni membentuk setiap insan menjadi warga negara yang baik, taat akan hukum dan mentaati peraturan perundang-undangan yang berlaku. Pendidikan merupakan salah satu faktor yang menjadi dasar maju atau tidaknya suatu bangsa, pendidikan sekarang menjadi kebutuhan yang sangat diwajibkan untuk mengikuti perkembangan suatu zaman. Perkembangan teknologi yang semakin pesat diharapkan dapat meningkatkan kualitas pendidikan karena dapat mempermudah pelaksanaan pembelajaran, oleh karena itu media pembelajaran mempunyai peran sangat penting dalam proses pembelajaran. Media pembelajaran merupakan sarana yang membantu proses pembelajaran terutama berkaiatan dengan indra penglihatan dan pendengaran seseorang. Di dalam Pancasila terkandung banyak nilai di mana dari keseluruhan nilai tersebut terkandung di dalam lima garis besar dalam kehidupan berbangsa negara. 
Perjuangan dalam memperebutkan kemerdekaan tak jua lepas dari nilai Pancasila. Sejak zaman penjajahan hingga sekarang, kita selalu menjunjung tinggi nilai-nilai Pancasila tersebut.

Indonesia hidup di dalam berbagai macam keberagaman, baik itu suku, bangsa, budaya dan agama. Dari ke semuanya itu, Indonesia berdiri dalam suatu keutuhan. Menjadi kesatuan dan bersatu di dalam persatuan yang kokoh di bawah naungan Pancasila dan semboyannya, Bhinneka Tunggal Ika.

Tidak jauh dari hal tersebut, Pancasila membuat Indonesia tetap teguh dan bersatu di dalam keberagaman budaya. Dan menjadikan Pancasila sebagai dasar kebudayaan yang menyatukan budaya satu dengan yang lain. Karena ikatan yang satu itulah, Pancasila menjadi inspirasi berbagai macam kebudayaan yang ada di Indonesia. 


\section{B. PEMBAHASAN}

Sumber Historis Pendidikan Pancasila, Presiden Soekarno pernah mengatakan, "Jangan sekali-kali meninggalkan sejarah." Pernyataan tersebut dapat dimaknai bahwa sejarah mempunyai fungsi penting dalam membangun kehidupan bangsa dengan lebih bijaksana di masa depan. Hal tersebut sejalan dengan ungkapan seorang filsuf Yunani yang bernama Cicero (106-43SM) yang mengungkapkan, "Historia Vitae 28 Magistra", yang bermakna, "Sejarah memberikan kearifan". Pengertian lain dari istilah tersebut yang sudah menjadi pendapat umum (common-sense) adalah "Sejarah merupakan guru kehidupan". Implikasinya, pengayaan materi perkuliahan Pancasila melalui pendekatan historis adalah amat penting dan tidak boleh dianggap remeh guna mewujudkan kejayaan bangsa di kemudian hari. Melalui pendekatan ini, mahasiswa diharapkan dapat mengambil pelajaran atau hikmah dari berbagai peristiwa sejarah, baik sejarah nasional maupun sejarah bangsa-bangsa lain. Dengan pendekatan historis, Anda diharapkan akan memperoleh inspirasi untuk berpartisipasi dalam pembangunan bangsa sesuai dengan program studi masing-masing. Selain itu, Anda juga dapat berperan serta secara aktif dan arif dalam berbagai kehidupan berbangsa dan bernegara, serta dapat berusaha menghindari perilaku yang bernuansa mengulangi kembali kesalahan sejarah. Gambar I.6: Pidato Presiden Soekarno Sumber: radiosilaturahim.com Dalam peristiwa sejarah nasional, banyak hikmah yang dapat dipetik, misalnya mengapa bangsa Indonesia sebelum masa pergerakan nasional selalu mengalami kekalahan dari penjajah? Jawabannya antara lain karena perjuangan pada masa itu masih bersifat kedaerahan, kurang adanya persatuan, mudah dipecah belah, dan kalah dalam penguasaan IPTEKS termasuk dalam bidang persenjataan. Hal ini berarti bahwa apabila integrasi 27 
diselenggarakan dan sebaiknya diselenggarakan sebagai mata kuliah yang berdiri sendiri dan harus dimuat dalam kurikulum masing-masing perguruan tinggi. Dengan demikian, keberadaan mata kuliah pendidikan Pancasila merupakan kehendak negara, bukan kehendak perseorangan atau golongan, demi terwujudnya tujuan negara. Anda dipersilakan untuk mendiskusikan dengan kelompok Anda hal-hal sebagai berikut:

1. mencari dari berbagai sumber tentang alasan pendidikan Pancasila diperlukan untuk negara Indonesia.

2. menemukan alasan pendidikan Pancasila harus dilaksanakan di perguruan tinggi.

3. menunjukkan apa yang akan terjadi apabila pendidikan Pancasila tidak diselenggarakan dalam dunia pendidikan Indonesia.

Kemudian Anda diminta untuk melaporkan secara tertulis untuk diserahkan kepada dosen. Menggali Sumber Historis, Sosiologis, Politik Pendidikan Pancasila Dilihat dari segi objek materil, pengayaan materi atau substansi mata kuliah pendidikan Pancasila dapat dikembangkan melalui beberapa pendekatan, diantaranya pendekatan historis, sosiologis, dan politik. Sementara, dilihat dari segi objek formil, pengayaan materi mata kuliah pendidikan Pancasila dilakukan dengan pendekatan ilmiah, filosofis, dan ideologis. Materi perkuliahan dikembangkan dari fenomena sosial untuk dikaji dan ditemukan solusinya yang rasional dan bertanggung jawab sesuai dengan nilai-nilai Pancasila oleh mahasiswa. Dengan demikian, kesadaran sosial mahasiswa turut serta dalam memecahkan permasalahan-permasalahan sosial. Hal ini akan terus bertumbuh melalui mata kuliah pendidikan Pancasila. Pada gilirannya, mahasiswa akan memiliki argumentasi bahwa mata kuliah pendidikan Pancasila bermakna penting dalam sistem pendidikan tinggi di tanah air. 1. Sumber Historis Pendidikan Pancasila Presiden Soekarno pernah mengatakan, ”Jangan sekali-kali meninggalkan 
sejarah." Pernyataan tersebut dapat dimaknai bahwa sejarah mempunyai fungsi penting dalam membangun kehidupan bangsa dengan lebih bijaksana di masa depan. Hal tersebut sejalan dengan ungkapan seorang filsuf Yunani yang bernama Cicero (106-43SM) yang mengungkapkan, "Historia Vitae 28 Magistra", yang bermakna, "Sejarah memberikan kearifan". Pengertian lain dari istilah tersebut yang sudah menjadi pendapat umum (common-sense) adalah "Sejarah merupakan guru kehidupan". Implikasinya, pengayaan materi perkuliahan Pancasila melalui pendekatan historis adalah amat penting dan tidak boleh dianggap remeh guna mewujudkan kejayaan bangsa di kemudian hari. Melalui pendekatan ini, mahasiswa diharapkan dapat mengambil pelajaran atau hikmah dari berbagai peristiwa sejarah, baik sejarah nasional maupun sejarah bangsa-bangsa lain. Dengan pendekatan historis, Anda diharapkan akan memperoleh inspirasi untuk berpartisipasi dalam pembangunan bangsa sesuai dengan program studi masing-masing. Selain itu, Anda juga dapat berperan serta secara aktif dan arif dalam berbagai kehidupan berbangsa dan bernegara, serta dapat berusaha menghindari perilaku yang bernuansa mengulangi kembali kesalahan sejarah. Pidato Presiden Soekarno Sumber: radiosilaturahim.com Dalam peristiwa sejarah nasional, banyak hikmah yang dapat dipetik, misalnya mengapa bangsa Indonesia sebelum masa pergerakan nasional selalu mengalami kekalahan dari penjajah? Jawabannya antara lain karena perjuangan pada masa itu masih bersifat kedaerahan, kurang adanya persatuan, mudah dipecah belah, dan kalah dalam penguasaan IPTEKS termasuk dalam bidang persenjataan. Hal ini berarti bahwa apabila integrasi 29 bangsa lemah dan penguasaan IPTEKS lemah, maka bangsa Indonesia dapat kembali terjajah atau setidak-tidaknya daya saing bangsa melemah. Implikasi dari pendekatan historis ini adalah meningkatkan motivasi kejuangan bangsa dan meningkatkan motivasi belajar Anda dalam menguasai 
IPTEKS sesuai dengan prodi masing-masing. Nilai-nilai Pancasila sudah ada dalam adat istiadat, kebudayaan, dan agama yang berkembang dalam kehidupan bangsa Indonesia sejak zaman kerajaan dahulu. Misalnya, sila Ketuhanan sudah ada pada zaman dahulu, meskipun dalam praktik pemujaan yang beranekaragam, tetapi pengakuan tentang adanya Tuhan sudah diakui. Dalam Encyclopedia of Philosophy disebutkan beberapa unsur yang ada dalam agama, seperti kepercayaan kepada 65 kekuatan supranatural, perbedaan antara yang sakral dan yang profan, tindakan ritual pada objek sakral, sembahyang atau doa sebagai bentuk komunikasi kepada Tuhan, takjub sebagai perasaan khas keagamaan, tuntunan moral diyakini dari Tuhan, konsep hidup di dunia dihubungkan dengan Tuhan, kelompok sosial seagama dan seiman. 


\section{C.PENUTUP}

\section{Kesimpulan}

Nilai-nilai Pancasila sudah ada dalam adat istiadat, kebudayaan, dan agama yang berkembang dalam kehidupan bangsa Indonesia sejak zaman kerajaan dahulu. Misalnya, sila Ketuhanan sudah ada pada zaman dahulu, meskipun dalam praktik pemujaan yang beranekaragam, tetapi pengakuan tentang adanya Tuhan sudah diakui. Dalam Encyclopedia of Philosophy disebutkan beberapa unsur yang ada dalam agama, seperti kepercayaan kepada 65 kekuatan supranatural, perbedaan antara yang sakral dan yang profan, tindakan ritual pada objek sakral, sembahyang atau doa sebagai bentuk komunikasi kepada Tuhan, takjub sebagai perasaan khas keagamaan, tuntunan moral diyakini dari Tuhan, konsep hidup di dunia dihubungkan dengan Tuhan, kelompok sosial seagama dan seiman. .

\section{Saran}

Demikianlah makalah berjudul Sumber Historis Pencasila Sebagai Dasar Negara ini saya buat berdasarkan sumber-sumber yang ada. Saya juga menyadari, masih ada banyak kekurangan di dalam penulisan makalah ini. Sehingga perlulah bagi saya,dan para pembaca untuk memberikan saran yang membantu supaya makalah ini mendekati lebih baik. Atas perhatiannya saya ucapkan terimakasih. 


\section{DAFTAR PUSTAKA}

Darmini Roza dan Laurensius Arliman S Peran Pemerintah Daerah Di Dalam Melindungi Hak Anak Di Indonesia, Masalah-Masalah Hukum, Volume 47, Nomor 1, 2018.

Laurensius Arliman S, Komnas HAM dan Perlindungan Anak Pelaku Tindak Pidana, Deepublish, Yogyakarta, 2015.

Laurensius Arliman S, Penguatan Perlindungan Anak Dari Tindakan Human Trafficking Di Daerah Perbatasan Indonesia, Jurnal Selat, Volume 4, Nomor $1,2016$.

Laurensius Arliman S, Problematika Dan Solusi Pemenuhan Perlindungan Hak Anak Sebagai Tersangka Tindak Pidana Di Satlantas Polresta Pariaman, Justicia Islamica, Volume 13, Nomor 2, 2016.

Laurensius Arliman S, Pelaksanaan Perlindungan Anak Yang Tereksploitasi Secara Ekonomi Oleh Pemerintah Kota Padang, Veritas et Justitia, Volume 2, Nomor $1,2016$.

Laurensius Arliman S, Kedudukan Ketetapan MPR Dalam Hierarki Peraturan Perundang-Undangan Di Indonesia, Lex Jurnalica, Volume 13, Nomor 3, 2016.

Laurensius Arliman S, Komnas Perempuan Sebagai State Auxialiary Bodies Dalam Penegakan Ham Perempuan Indonesia, Justicia Islamica, Volume 14, Nomor 2, 2017. 
Laurensius Arliman S, Peranan Pers Untuk Mewujudkan Perlindungan Anak Berkelanjutan Di Indonesia, Jurnal Ilmu Hukum Tambun Bungai, Volume 2, Nomor 2, 2017.

Laurensius Arliman S, Mewujudkan Penegakan Hukum Yang Baik Untuk Mewujudkan Indonesia Sebagai Negara Hukum, Jurnal Hukum Doctrinal, Volume 2, Nomor 2, 2017.

Laurensius Arliman S, Participation Non-Governmental Organization In Protecting Child Rights In The Area Of Social Conflict, The 1st Ushuluddin and Islamic Thought International Conference (Usicon), Volume 1, 2017.

Laurensius Arliman S, Partisipasi Masyarakat Dalam Pembentukan Perundang-Undangan Untuk Mewujudkan Negara Kesejahteraan Indonesia, Jurnal Politik Pemerintahan Dharma Praja, Volume 10, Nomor 1, 2017, https://doi.org/10.33701/jppdp.v10i1.379.

Laurensius Arliman S, Peran Komisi Perlindungan Anak Indonesia Untuk Mewujudkan Perlindungan Anak, Jurnal Respublica Volume 17, Nomor 2, 2018.

Laurensius Arliman S, Menjerat Pelaku Penyuruh Pengrusakan Barang Milik Orang Lain Dengan Mempertimbangkan Asas Fungsi Sosial, Jurnal Gagasan Hukum, Volume 1, Nomor 1, 2019.

Laurensius Arliman S, Ilmu Perundang-Undangan Yang Baik Untuk Negara Indonesia, Deepublish, Yogyakarta, 2019.

Laurensius Arliman S, Isdal Veri, Gustiwarni, Elfitrayenti, Ade Sakurawati, Yasri, Pengaruh Karakteristik Individu, Perlindungan Hak Perempuan Terhadap Kualitas Pelayanan Komnas Perempuan Dengan Kompetensi Sumber Daya Manusia Sebagai Variabel Mediasi, Jurnal Menara Ekonomi: Penelitian dan Kajian Ilmiah Bidang Ekonomi, Volume 6, Nomor 2, 2020.

Laurensius Arliman S, Pendidikan Kewarganegaraan, Deepublish, Yogyakarta, 2020. 
Laurensius Arliman S, Makna Keuangan Negara Dalam Pasal Pasal 23 E Undang-Undang Dasar 1945, Jurnal Lex Librum, Volume 6, Nomor 2 Juni 2020, http://dx.doi.org/10.46839/lljih.v6i2.151.

Laurensius Arliman S, Kedudukan Lembaga Negara Independen Di Indonesia Untuk Mencapai Tujuan Negara Hukum, Kertha Semaya Journal Ilmu Hukum, Volume 8, Nomor 7, 2020.

Laurensius Arliman S, Pelaksanaan Assesment Oleh Polres Kepulauan Mentawai Sebagai Bentuk Pelaksanaan Rehabilitasi Bagi Pecandu Dan Korban Penyalahgunaan Narkotika, Jurnal Muhakkamah, Volume 5, Nomor 1, 2020.

Laurensius Arliman S, Aswandi Aswandi, Firgi Nurdiansyah, Laxmy Defilah, Nova Sari Yudistia, Ni Putu Eka, Viona Putri, Zakia Zakia, Ernita Arief, Prinsip, Mekanisme Dan Bentuk Pelayanan Informasi Kepada Publik Oleh Direktorat Jenderal Pajak, Volume 17, No Nomor, 2020.

Larensius Arliman S, Koordinasi PT. Pegadaian (Persero) Dengan Direktorat Reserse Narkoba Polda Sumbar Dalam Penimbangan Barang Bukti Penyalahgunaan Narkotika, UIR Law Review, Volume 4, Nomor 2, 2020, https://doi.org/10.25299/uirlrev.2020.vol4(1).3779.

Laurensius Arliman S, Tantangan Pendidikan Kewarganegaraan Pada Revolusi 4.0, Ensiklopedia Sosial Review, Volume 2, Nomor 3, 2020.

Muhammad Afif dan Laurensius Arliman S, Protection Of Children's Rights Of The Islamic And Constitutional Law Perspective Of The Republic Of Indonesia, Proceeding: Internasional Conference On Humanity, Law And Sharia (Ichlash), Volume 1, Nomor 2, 2020.

Otong Rosadi danLaurensius Arliman S, Urgensi Pengaturan Badan Pembinaan Idelogi Pancasila Berdasarkan Undang-Undang Sebagai State Auxiliary Bodies yang Merawat Pancasila dalam Perspektif Hak Asasi Manusia, Prosiding Konferensi Nasional Hak Asasi Manusia, Kebudayaan dan Tujuan Pembangunan Berkelanjutan Indonesia pada Masa Pandemi Covid-19: Tantangan untuk Keilmuan Hukum dan Sosial Volume 1, Universitas Pancasila, Jakarta, 2020. 
